Apidologie, 1978, 9 (2), 111-116.

\title{
LABORATORY COMPARISON OF HIGH FRUCTOSE CORN SYRUP, GRAPE SYRUP, HONEY, AND SUCROSE SYRUP AS MAINTENANCE FOOD FOR CAGED HONEY BEES
}

Roy J. BARKER and Yolanda LEHNER

U.S. Department of Agriculture, Agricultural Research Service, Bee Research Laboratory, 2000 East Allen Road, Tucson, Arizona 85719

\section{SUMMARY}

Honey or high fructose corn syrup fed to worker bees failed to show any advantage over sucrose syrup. Grape syrup caused dysentery and reduced survival. Caged bees survived longest on sucrose syrup.

\section{INTRODUCTION}

A commercial process utilizes glucose isomerase to convert the glucose from hydrolyzed corn starch to a mixture containing glucose and high levels of fructose (Ashengreen, 1975). To humans, fructose is sweeter than glucose or sucrose. Consequently, the higher the content of fructose, the lower the concentration of sugar needed to sweeten food or drinks. Thus, high fructose corn syrup is an economical sweetener for humans.

Does isomerized corn syrup provide advantages in bee foods? Its sugar composition closely resembles that of honey, but isomerized sugar may not be sweeter than sucrose to honey bees. In fact, a preference of older bees for sucrose over glucose and fructose may explain why they leave hives containing stored honey to forage for nectar. Nevertheless, beekeepers generally consider honey to be unparalleled as a bee food despite its failure to sustain worker bees as long as sucrose (BARKER and LeHNER, 1974 a, b). High fructose corn syrup offers advantages besides lower cost, such as feeding convenience. Furthermore, some beekeepers find 
less robbing when bees are fed high fructose corn syrup instead of sucrose syrup. This may be a consequence of lower attraction. No one sugar seems to match sucrose for acceptance or for survival value (BARKER, 1977; BARKER and LeHNER, $1974 \mathrm{c}, \mathrm{d}$ ).

Fructose is sometimes called " grape sugar " because grapes contain so much of it. Pomace from crushed grapes attracts honey bees (FEO et al., 1957), and sometimes bees are blamed for damage to ripe grapes. However, RADOEv (1971) found that grape juice was toxic to honey bees. We hoped that commercially available grape syrup would be attractive and nutritious for honey bees.

Our objective was to compare sucrose syrup, honey, high fructose corn syrup, and grape syrup for sustenance of honey bees and for acceptance, comb-building, and hoarding by bees.

\section{MATERIALS AND METHODS}

Bees shaken from combs of brood were held in small $(24 \times 24 \times 8 \mathrm{~cm})$ cages for $24 \mathrm{hr}$. Each cage contained ca. 1,200 bees and a rack holding two wooden bars $25 \mathrm{~cm}$ long with a $2 \times 2 \mathrm{~cm}$ piece of comb foundation centered on one bar. A caged queen was attached to a bar beside the foundation. After $48 \mathrm{hr}$, the bees had settled on the bars and were building comb. Then, the queen cage was moved to an end of the bar, and bees were released from the small cage into a larger $(56 \times 56 \times 43 \mathrm{~cm})$ cage.

The room with the three replicate cages of bees for each treatment was maintained at $28 \pm 1{ }^{\circ} \mathrm{C}$ and $20 \%$ RH with a $3 \mathrm{hr}$ photoperiod. Aluminum foil on a rack held below fluorescent ceiling lights served to reduce clustering at the top of cages when lights were on.

Dead bees were removed and counted daily for 60 days. "Bee days " were obtained by adding the numbers of bees alive each day. Samples of dead bees were checked for nosema disease.

We tested the following sugars:

High fructose corn syrup (Isomerose 100 Brand High Fructose Corn Syrup; lot 22, Clinton Corn Processing Co., Inc. Clinton, IA 52732).

Grape syrup (white grape juice concentrate $68^{\circ}$ Brix, sample TK 45, Delano Growers Co-op Winery, Delano, CA 93215).

Sucrose (C and $\mathrm{H}$ Brand table sugar from a grocer).

Honey (unfiltered, unhealed from mixed flora at Tueson, AZ, less than 1 year old).

Water was added to give syrups with refractometer readings of $50 \%$. (This is $50 \% \mathrm{u} / \mathrm{v}$ for sucrose, but about $52 \%$ for the other sugars.) The syrups were fed from inverted jars with perforated lids. Water was supplied separately although very little was taken. Both jars rested on the parallel wood bars that supported combs. Fresh, weighed jars of syrups were supplied daily, and consumption was measured by changes in weight of the jars. Jars held without bees had very low weight loss so corrections were not necessary for a blank.

Data were recorded for number of dead bees each day, weight of syrup removed each day, weight of wax produced, weight of syrup (honey?) stored in new comb, number of cells and number of sealed cells of honey comb, and size of cells. The data were subjected to analysis of variance. Where a significant difference was shown by an $F$ test, a Student-Neuman-Keuls multiple range test was used to establish which treatments differed from one another.

Sugars in the syrups and in capped honey from combs were identified by two-dimensional thin-layer chromatography. After diluting with water 1 to 100,1 to $3 \mu l$ aliquots were spotted onto silica gel $G$ plates. These were developped twice in one direction with $n$-butanol-acetone-water (4:5:1) and twice in 
the perpendicular direction with phenol-water $(3: 1)$ and then stained with Saini's p-aminobenzoic acid reagent for qualitative identification (BARKER and LEHNER, $1974 \mathrm{~d}$ ).

Comb wax was dissolved in benzene $(40 \mu \mathrm{g} / \mu \mathrm{l})$, and $1-2 \mu 1$ were spotted onto a plate of silica gel G. These plates were developed in benzene and charred at $120^{\circ} \mathrm{C}$ with fresh $40 \%$ sulfuric acid in ethanol to identify classes of lipids.

\section{RESULTS}

Differences between tests in the number of bees per cage were not significant. In all cages fed grape syrups, bees soon developed dysentery. The checks for nosema disease were negative except for a few bees fed honey; these had less than 15 spores per bee. Thus, disease was not a problem.

Survival was longest on sucrose syrup, and the difference was significant. Survival on grape syrup was reduced significantly. The difference between honey and high fructose corn was non-significant (Table 1).

Consumption per bee day, wax production per bee day, ratios of honey stored to syrup consumed, number of capped cells of honey, and ratio of wax produced to syrup consumed were all significantly less for bees fed grape syrup. The differences between honey, sucrose, and high fructose corn syrup were not statistically significant for any of these measurements (Table 1).

TABLE 1. - Summary of results (means $\pm S D$ ).

Data underlined by the same line do not differ at $5 \%$ probability level.

\begin{tabular}{|c|c|c|c|c|c|}
\hline Measurement & \multicolumn{2}{|c|}{ Sucrose } & Honey & $\begin{array}{l}\text { High Fructose } \\
\text { Corn Syrup }\end{array}$ & Grape Syrup \\
\hline $\mathrm{LT}_{50}$ (days) & $56.3 \pm$ & 8.1 & $31.3 \pm 2.5$ & $37.7 \pm 2.1$ & $13.3 \pm 1.2$ \\
\hline mg. consumption/bee day & $59.0 \pm$ & 6.9 & $66.3 \pm 13.7$ & $60.1 \pm 3.2$ & $31.8 \pm 8.1$ \\
\hline $\mathrm{mg}$. honey/bee day & $10.4 \pm$ & 1.4 & $13.4 \pm 5.8$ & $10.3 \pm 1.2$ & $.6 \pm .7$ \\
\hline mg. wax/bee day & $.73 \pm$ & .10 & $.73 \pm .15$ & $.69 \pm .05$ & $.23 \pm .08$ \\
\hline honey/syrup .. & $.177 \pm$ & .017 & $.195 \pm .045$ & $.171 \pm .013$ & $.016 \pm .016$ \\
\hline wax/syrup & $.012 \pm$ & .006 & $.011 \pm 0$ & $.011 \pm .007$ & $.008 \pm .007$ \\
\hline capped cells .. & 538 & & \pm 39 & \pm 45 & 0 \\
\hline
\end{tabular}

The following sugars were detected :

Grape syrup : glucose, fructose only - no trace of other sugars.

High fructose corn syrup : fructose, glucose, faint traces of sucrose, and a faint trace of unknown with an $\mathrm{R}_{\mathrm{f}}$ near melezitose.

Honey : fructose, glucose, and traces of sucrose and maltose.

"Honey " from grape syrup : insufficient available. 
"Honey " from high fructose corn syrup : glucose and fructose with traces of maltose and unknown (melezitose?).

" Honey " from honey : fructose, glucose, sucrose, and maltose with traces with traces of melezitose and raffinose.

"Honey" from sucrose : fructose, glucose, and sucrose with traces of maltose and melezitose.

Waxes from the different syrups showed no obvious qualitative differences with preliminary chromatographic analyses.

Cell diameter and wall thickness did not differ significantly when measured under calibrated binoculars. The wall thicknesses were highly variable.

\section{DISCUSSION AND CONCLUSION}

We had suspected that grape syrup contained toxic galactosides because galactosides cause dysentery and are common constituents of plant juices. However, chromatography failed to confirm this. The manufacturer suggested that sulfur dioxide might be the toxin. Nevertheless, a different sample that was low in sulfur dioxide was also toxic.

The survival data agree with our earlier reports that no sugar sustains bees better than sucrose.

Received in October 1977.

\section{ACKNOWLEDGMENT}

Stephen TABER III of ARS, USDA gave helpful advice on beekeeping. Technical assistance by Michael Kunzmann is appreciated. Dr. Richard E. Daehler, Clinton Corn Processing Co., supplied Isomerose-100 Brand High Fructose Corn Syrup and information on its sugar composition. Harold RoLAND, Delano Growers Co-op Winery, supplied grape syrup.

The use of a trademark does not constitute an endorsement of a product by the USDA.

\section{ZUSAMMENFASSUNG}

EIN LABORVERGLEICH VON STARK FRUKTOSEHALTIGEM MAISSIRUP,

TRAUBENSIRUP, HONIG UND ROHRZUCKERSIRUP

ALS ERHALTUNGSFUTTER FÜR GEKÄFIGTE HONIGBIENEN

Die gekäfigten Honigbienenvölker verzehrten weniger Traubensirup als Rohrzuckersirup, Honig oder stark fruktosehaltigen Maissirup. Die mit Rohrzuckersirup gefütterten Bienen lebten am längsten. Traubensirup rief schwere Ruhr hervor und verminderte die Lebensdauer. Die mit Traubenzucker gefütterten Bienen erzeugten weniger Honig und weniger Wachs.

Im Traubensirup wurden keine giftigen Galaktoside gefunden. Die giftige, Ruhr erzeugende Substanz bleibt unbestimmt. 


\title{
RÉSUMÉ
}

\author{
ÉTUDE COMPARATIVE AU LABORATOIRE DU SIROP DE MAIS \\ A FORTE TENEUR EN FRUCTOSE, DU SIROP DE RAISIN, \\ DU MIEL ET DU SIROP DE SACCHAROSE COMME PRODUIT DE NOURRISSEMENT \\ POUR ABEILLES ENCAGÉES.
}

Les colonies d'abeilles encagées ont consommé moins de sirop de raisin que de sirop de saccharose, de miel ou de sirop de maïs à forte teneur en fructose. Les abeilles nourries au sirop de saccharose ont vécu plus longtemps, tandis que le sirop de raisin a diminué la longévité. Les abeilles nourries au sirop de raisin ont également produit moins de miel et moins de cire.

Aucun galactoside toxique n'a été mis en évidence dans le sirop de raisin; la substance toxique qui cause une forte dysenterie n'a pas été identifiée.

\section{REFERENCES}

Ashengreen N.H., 1975. - Production of glucose/fructose syrups. Process Biochem., 10 (4) : 17.

BARKER R. J., 1977. - Considerations in selecting sugars for feeding to honey bees. Am. Bee J., 117 : 76 77.

BARKER R. J. and Y. LEHNER., 1974 a. - Acceptance and sustentative values of honey, the sugars of honey, and sucrose fed to cages of honey bee workers. Am. Bee J., $113: 370-371$.

BARker R. J. and Y. LehNer., 1974 b. - Food choice changes in aging honey bees. Ann. ent. Soc. Am., $67: 717-718$.

BARKER R. J. and Y. LEHNER., $1974 \mathrm{c}$. - Acceptance and sustenance value of naturally, occurring sugars fed to newly emerged adult workers of honey bees (Apis mellifera L.). J. exp. Zool., 187 : 277-286.

BARKER R. J. and Y. LEHNER., 1974 d. - Influence of diet on sugars found by thin-layer chromatography in thoraces of honey bees; Apis mellifera L. J. exp. Zool., $188: 157-164$.

Feo E. G., E. D. Feldman and H. M. Goetz., 1957. - Bee Food Composition. U. S. Patent 2, 895, 829.

RADOEV L., 1971. - [Testing of the influence of grape juice and grape honey on the wintering and spring development of bees colonies.] In Bulgarian. Zhivotnovdni Nauk, 8 : 137-144. 